\title{
A Doctrinal Approach to Property Law Scholarship: Who \\ Cares and Why?
}

\section{Introduction}

The debate about the proper approach to research in law - let alone property law - is one that has come to the front and centre of academic attention in recent years. Of course, it is not a new issue. ${ }^{1}$ But it has been given fresh impetus now that that research funding in some jurisdictions is tied to a "value for money" framework that sees "value" in terms of "impact" and "impact" means measurable outcomes. Or, to strip away the jargon-heavy vocabulary: research has to have a practical point, obvious to those paying for it. If this spills over into consequences for academic careers and career progression, either because law schools need people with funding, or because those making appointments believe that there is a "right" (and therefore a "wrong") way to conduct research, then what could have been regarded as a diverting theoretical argument becomes an issue of considerably more significance. ${ }^{2}$

Like everyone approaching the question of how to research into law - whether we call it an analysis of research methodology or an exercise in how to fill in a grant application - I do not approach this free of prejudice. At the general level, however, my prejudice is not against (or for) any particular approach to legal scholarship. But, it is against the idea that one approach is to be preferred over another. The idea that doctrinal research into law is "dead"3 or that special "clinical" schools can be set up where those engaged in "merely" identifying the rules of a legal system can be

\footnotetext{
${ }^{1}$ The literature is vast, but see especially Posner R, "The Present Situation in Legal Scholarship" 90 Yale LJ 1113 (1980-1981); Rubin E, "Law and the Methodology of Law" [1997] Wisconsin Law Review 521; Schlag P, "Spam Jurisprudence, Air Law, and the Rank Anxiety of Nothing Happening (A Report on the State of the Art)", 97 GEO LJ 803 (2009); Posner R, "The State of Legal Scholarship Today (A Comment on Schlag)" 97 GEO L J 845 (2009); Siems M and Mac Sithigh D, "Mapping Legal Research" 71 CLJ 651 (2012); Hutchinson T, "Doctrinal research: researching the jury" in Watkins D and Burton M (eds), Research Methods in Law (Routledge, London, 2013) 7

${ }^{2}$ See Siems M and Mac Sithigh D, n 1 at 674-5.

${ }^{3}$ Posner E, "The Rise of Interdisciplinary Approaches in American Legal Scholarship", keynote address at the University of Tilburg Symposium, Towards a European Legal Methodology?, 2008, quoted by van Gestel R and Micklitz H-W, n 6.
} 
housed, ${ }^{4}$ is not offensive to me because it downgrades doctrinal scholarship: it is offensive because it downgrades. ${ }^{5}$ While it is unavoidable that scare resources for research will have to be allocated among a much larger pool of researchers, it diminishes both the argument and the protagonist if this mutates into an argument about why certain methodologies (and by extension those adopting them) are more "important" or "worthy" than others. Of course, someone will have to make a judgement about what to fund and who to appoint, and it is entirely right that the nature of the research will play a pivotal role. But that is not the same as concluding, or promoting the idea, that a whole way of researching should ex hypothesi be regarded as second rate or, even worse, denied the label "research" at all.

It is against the background of this prejudice that I want to think about a doctrinal approach to property law scholarship. ${ }^{6}$ It is not the purpose of what follows to defend a doctrinal approach against those who would argue against it as a methodology. The purpose is to seek to explain what a doctrinal approach is, why it has value alongside other methodologies and what its limitations are. Where appropriate, I will seek to illustrate with examples of doctrinal scholarship from England \& Wales, drawing on the extensive statutory material and the judiciary's continuing development of the common law.

\section{The What and the How}

A doctrinal approach to property law is initially the search for what the law is, not what it should be. That does not mean to say that a scholar engaged in the search for the norms of, say, the law concerning registered title, is unconcerned with inconsistencies or conflicts, and certainly a rigorous doctrinal analysis should sit within the framework of the policy aims of (say) the legislation that is being analysed. Yet, the "research" proceeds on the basis that it is important to expose the norms applicable to the area of property law under examination. So, when a property lawyer

\footnotetext{
${ }^{4}$ See Posner R in "A Comment on Schalg", n 1 at 854.

${ }^{5}$ In fairness, Richard Posner in "A Comment on Schlag", n 1, does not seek to downgrade doctrinal scholars and scholarship, but the suggestion of separation and that they might have a heavier teaching load will, one suspects, have that effect.

${ }^{6}$ See also, from a large potential pool of writing, van Gestel R and Micklitz H-W, "Revitalizing Doctrinal Legal Research in Europe: What About Methodology?" EUI Working Papers 2001/05; Van Hoecke M, "Legal Doctrine: Which Method(s) for What Kind of Discipline?" in Van Hoecke M, Methodologies of Legal Research (Hart, London 2013) 1 ; Hutchinson TC and Duncan N, "Defining and describing what we do: doctrinal legal research" (2012) 17 Deakin Law Review 83.
} 
engaged in doctrinal research talks of critical analysis, they mean a dissection of the law as is, examining it for consistency and coherence, as well as a critical appreciation of the law in terms of policy-compatibility and future development. Furthermore, while it is true that "simply" stating the law looks more like ruleidentification rather than rule analysis, this often masks a much more complex task that is easily undervalued. For example, taking a case, and a set of rules, very familiar to property lawyers in this jurisdiction of all research persuasions - Stack v Dowden ([2007] 2 AC 432, [2007] UKHL 17) and the law of implied trusts [see also Blandy; Eds] - any critic who suggests that a doctrinal property lawyer "simply" states what the case decides, clearly has not read it. ${ }^{7}$ In many cases, the most difficult research question of all is "what is the law?" and those engaged in doctrinal analysis will seek to answer this.

A doctrinal analysis of an area within property law commonly has the following features. Given that I would reject any attempt to rank research methodologies in order of importance or value, these features should not be regarded as prescriptive or definitional. However, they will be familiar to those engaged in the enterprise.

(i) The researcher will focus on a reasonably well-defined area of property law, apparently (but not actually) in ignorance of broader conceptual concerns. The focus might be to examine a thread running across a wider topic (for example, the meaning of title guarantee under the Land Registration Act 2002, or a closed-off issue with well defined parameters (for example, the circumstances in which a court will order sale of co-owned land under section 14 of the Trusts of Land and Appointment of Trustees Act 1996). This can lead to the criticism that the researcher lacks "breadth of vision" or fails to add to the broader fund of knowledge because the author does not explain how this work fits into one of the "accepted" theoretical models of how property law works. Certainly, it is true that those engaged in doctrinal research rarely seek to justify their work within an over-arching theoretical framework - such as an

\footnotetext{
${ }^{7}$ The dispute involved an unmarried couple who, when their relationship broke down, argued over how much each owned in the family home. The formal title to the house was owned jointly, but as a matter of statute this imports a trust: Law of Property Act 1925 ss 35, 36. The real issue was therefore how much of the equitable interest each owned. Prior to the case, it was safe to assume that, absent any written statement, the co-owners also owned the equitable interest "jointly". In Stack, it became clear that it was possible to displace this presumption of joint ownership by relying on "exceptional" circumstances and so Ms Dowden was declared to own roughly 65\% and Mr Stack roughly 35\%.
} 
economic analysis of law or a critical legal studies analysis - but the reason is not that this could not be done; it is rather that it is not the point of what is being done.

(2) The research rarely commences with a literature review, at least not in the accepted social science sense. This is, of course, entirely consistent with the absence of any attempt to locate the research within a wider field of theoretical understanding. That is not to say, however, that those engaged in doctrinal research fail to incorporate academic literature. The research is not all about "the rules". Typically, however, the wider literature will appear in footnotes as examples of the work of academics who have taken a different view of the law, or approached the topic with a different methodology, or who have already commented on the material. The review of the surrounding literature is intended to be a guide, a help to the reader, a pointer to the work of others: it is not typically an attempt to justify the research in terms of a theory that is "accepted" as the proper framework for such research. For those engaged in doctrinal research, no further justification is needed other than the task of identifying what the law is and the inconsistencies it contains.

(3) It is rare for doctrinal researcher in property law to denigrate the work of others. This not because doctrinal researchers are saintly, or uncommonly respectful, but that the focus of the work is on what the law is, not how it relates to an over-arching conception, or even (at least initially) what the law should be. A doctrinal researcher is not in the business of explaining, primarily, why others are "wrong" because they would argue that theirs is a search for an objective statement of existing norms. Of course, many would challenge the assumption underpinning this - that it is possible to discover what the law is in isolation from the social and economic context in which it operates - and there is sometimes an arrogance about doctrinal scholarship that is unattractive. Yet, the search for apparently objective answers removes the need to engage in a systematic destruction of the theories of others. That is why many doctrinal researchers cannot quite understand the criticism of their work - which may lead to rejection by journals when submitted for publication - that it does not "relate to" or "engage with" this theory, or that theory, or the work of this or that scholar. As they see it, their research is not about the work of others, but about the law. Of course, many, many examples exist of doctrinal arguments and disagreements over what the 
law is, ${ }^{8}$ but rarely do they dissolve into an attack on the intellectual integrity of those with opposing views.

(4) The methodology itself is, usually, a close textual analysis of statute and/or the analysis of as much case law as can be discovered. It is the examination of primary materials in order to reach a conclusion about either a specific problem or a conclusion about a set of rules - a "doctrine" - of general application. An example of the former is an analysis of statute and case law to see how courts approach the question of sale of co-owned land under section 14 of the Trusts of Land and Appointment of Trustees Act $1996,{ }^{9}$ and of the second the use of the same working method to see how title guarantee and indemnity are configured under the Land Registration Act 2002. ${ }^{10}$ However, whatever the purpose of the enquiry, the first step is the gathering of relevant statute and case law in order to state conclusions about the law. In property law, for the doctrinal scholar, the more case law the better. Moreover, the doctrinal researcher sees value in both the process of "law discovery" and the result of the discovery. For many such researchers, the elucidation of the current law is a goal in itself, and they would argue that such an enquiry is not only necessary for other types of research, but is of itself sufficient to justify the energy and effort. It is, of course, a large claim that a sound doctrinal foundation is necessary for other types of research - and not one that all doctrinal researchers would subscribe to - but perhaps it is not going too far to suggest that a sound analysis of "where we are now" adds weight to work that seeks to take property law away from its rule-centric past.

Certainly, those engaged in doctrinal research find it difficult to be persuaded by the work of scholars who make claims about what the law should be, or the policy goals it should implement, if that work appears to proceed without an understanding of what the law is now. A current example is the debate over the meaning of "guarantee" and "mistake" under the Land Registration Act 2002 such as would be sufficient to justify

\footnotetext{
${ }^{8}$ For example, Ferris G and Battersby G, "The Impact of the Trusts of Land and Appointment of Trustees Act 1996 on Purchasers of Registered Land" [1998] Conv 168, challenged in Dixon M, "Has Flegg been overruled? Overreaching and the Trusts of Land and Appointment of Trustees Act 1996" [2000] Conv 267; rebutted in Ferris G and Battersby G, "Overreaching and the Trusts of Land and Appointment of Trustees Act 1996 - a reply to Mr. Dixon" [2001] Conv 221.

${ }^{9}$ For example, Dixon M, "To sell or not to sell: that is the question: the irony of the Trusts of Land and Appointment of Trustees Act 1996" (2011) 70 CLJ 579.

${ }^{10}$ For example, Lees E, "Title by Registration: Rectification, Indemnity and Mistake and the Land Registration Act 2002” [2013] 76 MLR 62.
} 
an alteration or rectification of the register. There is much to be said for the view even though I would not subscribe to it - that the Land Registration Act 2002 gives too much recognition to the formal act of title registration and too little to the general population's underlying social, economic and emotional conception of "ownership". However, an argument that proceeds in ignorance or deliberate misinterpretation of the actual statutory provisions and the surrounding case law will carry little weight with a doctrinal scholar. No doubt it is not the intention, but a research methodology that eschews at least some assessment of the current state of the law can give the appearance of bending the law to fit the argument, rather than making the argument to change the law.

(5) A typical result of a doctrinal analysis of property law is a statement of the state of the law as it now is, combined with an attempt to explain any revealed inconsistencies in the case law. ${ }^{12}$ However, that explanation (of the inevitable inconsistencies) is rarely located in an appeal to "policy" or empirical evidence, but rather in an analysis of why the deviant case has to be regarded as "wrongly decided" or, more respectfully, "decided by reference to its own special facts". There is an understanding that the rules will not form an entirely cohesive and coherent doctrine, but there may be an unspoken desire that it should! Thus, the primary aims are usually synthesis, explanation and clarity. These might not be the final destination of the doctrinal analysis, but for many it is the sine qua non. This is, however, where much of the criticism of the doctrinal approach has its roots. If all that the doctrinal researcher is doing is stating the current law, what value does it adds to the advancement of legal science? After all, if we all know that water contains two hydrogen atoms and one oxygen atom, simply stating this adds nothing to the general fund of knowledge. Of course - so the criticism runs - people need to know what the law is (especially, it is implied, for the important, practical but intellectually inferior task of advising clients) but pointing that out is not "research": it is "teaching", even if it is accompanied by a little digging. Such "teachers" can take their place in the world

\footnotetext{
${ }^{11}$ See, for example, the different approaches taken in Walker v Burton [2013] EWCA Civ 1228 and Fitzwilliam v Richall Holdings Services Ltd [2013] EWHC 86 (Ch), noted by Dixon M, [2013] 129 LQR. 320; Cooke E, [2013] 77 Conv 344 and Lees E, [2013] 76 MLR 924.

12 There are other ways of conducting work that might be referred to as doctrinal research, in particular an approach to scholarship sometimes referred to as 'interpretative legal theory'. See, for example, Beever A and Rickett C, "Interpretive Legal Theory and the Academic Lawyer" [2005] 68 MLR 320.
} 
of legal scholarship, often in specialist institutions, but such academics bear the same relation to "true" researchers as roadside car mechanics do to F1 engine designers. Useful in getting us from A to B, but not testing the boundaries of the possible and not adding to the sum of human knowledge.

Unsurprisingly, such an approach does not endear itself to a doctrinal researcher, or to practitioners for that matter [see also Malloy; Eds]. First, it begins with the mistaken assumption that it is a straightforward matter to determine what the law actually is. I do not mean by this that it is unclear how the known law might be applied to novel fact situations. That is the stuff of everyday legal practice and, of course, is something that all types of property law researcher has an interest in. Rather, it is the recognition that "the law" itself might be unclear, as where an apparently simply statutory phrase has no determined meaning, or case law is inconsistent. An example of the former is the meaning of "mistake" within Schedule 4 to the Land Registration Act 2002, and the later the scope of implied trusts after Stack v Dowden. It is not a question of "simply" reading the statute or the cases to find out what the law is, but instead requires the application of critical skills and synthesis. Secondly, in many cases, the rejection of the value of the search for the law as it now is carries with it an inherent, but hidden, diminishing of the value of exposition as an educative tool. The idea that an academic who is interested in discovering what the law is, is fit "merely" to be a teacher (because anyone can discover what the law is), and that teaching can be left to those who cannot "research" is, thankfully, not one that has much credit in common law jurisdictions. It is misplaced because the skills of analysis that make a good doctrinal researcher, are the same skills needed by good teachers and by good researchers engaged in other research methodologies. For a doctrinal scholar, teaching and research are complimentary, not alternatives. If you do not know that two hydrogen atoms and one oxygen atom makes water, how do you know whether you can drink the colourless liquid in your glass, and how will you exploit all its potential?

\section{The Why and the Why Not}

While legal research rightly now embraces all types of research methodologies, doctrinal analysis has been the predominant mode of research in the common law 
world and perhaps more so in property than any other area of law. There is a good reason for this. Land is a fixed, finite and immoveable resource. It forms the basis of much economic activity and personal wealth. There is a considerable amount of policy-based and empirical research which demonstrates that guarantee of title, easy alienability of interests and security of lending is critical to economic growth. ${ }^{13}$ This is a message taken seriously by most common law property jurisdictions. ${ }^{14}$ It was at the heart of the great property reforms in England and Wales in 1925 and is a primary reason for the reform of the land registration system by the Land Registration Act $2002 .^{15}$ In such an atmosphere, it is plain that there needs to be certainty about the legal rules. Thus, in the field of property law, doctrinal analysis which seeks to identify and codify the rules, based on statute and precedent, supports what is seen to be a core function of property law. ${ }^{16}$ Doctrinal analysis has a value in property law that almost speaks for itself. ${ }^{17}$

That, however, can make doctrinal property law scholars lazy. Knowing that the identification of legal rules is a valuable goal in itself, because legal certainty is so important in property law, ${ }^{18}$ sometimes encourages the belief that this approach should be the start and the end of the enquiry. However, if this - the identification of existing rules - is the limit of the enquiry, then doctrinal research will fail to engage with the wider research community and fails to address the social and economic reality in which the rules sit. There is a point in rule identification - but the point of rule identification is not the identification. It is to provide a framework for those lawyers that advise clients; to help define the problem for those that seek to develop the law in order to achieve policy goals; to help those who would persuade others, on the basis of empirical evidence, that the existing law is failing to achieve its aims; and to ensure that there is confidence in the integrity and objectivity of the legal system. Take Stack

\footnotetext{
${ }^{13}$ Famously, de Soto H, The Mystery of Capital (Basic Books, Reprint 2000), challenged, inter alia, by Woodruff C, "Review of de Soto's "The Mystery of Capital"” in (2001) 39 Journal of Economic Literature, 1215. See a challenge based on empirical research in Galiani S and Schargrodsky E, "Property Rights for the Poor: Effects of Land Titling", Ronald Coase Institute, Working Paper Series, No 7 Revised (2009).

${ }^{14}$ This is, of course, a perfect example of why a single approach to research in property law is a folly.

${ }^{15}$ I note in passing the argument, made by doctrinal scholars after examining the rules, that in fact the Land Registration Act 2002 in England \& Wales is not truly reforming - just tinkering.

${ }^{16}$ For example, one reason why there is so much interest in the reach of proprietary estoppel is because it challenges legal certainty in property matters.

${ }^{17}$ Perhaps this explains why so many respondents to the survey of research undertaken by property scholars reported that they were engaged in doctrinal research. The belief may well be that it is what property lawyers are meant to do because it reflects what property law is meant to do.

${ }_{18}$ And, of course, the idea that this is what property law should be about can, should, and is, challenged by researches using other methodologies.
} 
$v$ Dowden. The doctrinal scholar has problems with the judgment in this case because it generates uncertainty and lacks coherency with previous rules. It is even difficult to determine what the ratio decidendi of the case is - the worst kind of uncertainty for a doctrinal scholar. But simply making this point, and suggesting that the decision cannot be followed save in cases falling within its own factual limits ${ }^{19}$ (i.e. where land is held jointly and there is uncertainty about the beneficial entitlement), misses the target and consequently undersells the value of doctrinal scholarship. It ignores the policy questions around who should own co-habited property; it ignores the empirical research that reveals that "the law" of co-ownership is misunderstood and falling behind the reality of how people live their lives; it ignores the economic and social impact of imprecision and fails to measure it; and it reinforces the idea that doctrinal research is pedestrian and uninformed. In other words, doctrinal scholarship in a vacuum loses much of its value.

\section{The where next}

There is a perception, and perhaps it is no more than that, that the heyday of doctrinal legal scholarship has passed. Certainly, it is not a novel methodology and unlikely to be "the next best thing". It can be criticised as being outmoded, harking back to a time when both research and teaching was rigid and black letter. The implication is that it is not fit for purpose in the modern legal world. Doctrinal scholars sometimes counter this by pleading that the skills required to engage in a critical analysis and synthesis of a mass of primary materials are not easily come by. The implication is that doctrinal analysis is "hard" and those who eschew it, cannot do it. Neither of these assertions are helpful, and both are misplaced. There is, of course, a role for all types of research methodology in property law and, as noted above, doctrinal research supports one of the core concerns of modern property law - legal certainty. But not only do other methodologies dispute that legal certainty should be the main concern of land law, they challenge the smug certainty of the doctrinal scholar that the systemisation of legal rules is inherently valuable. It is up to doctrinal scholars to meet the challenges revealed by other methodologies and to explain why what they do is important. Failing to do that is a failure of doctrinal legal scholarship.

\footnotetext{
${ }^{19}$ Not should not, but cannot, because it falls outside established doctrine and precedent.
} 
